\title{
The Villisca Axe Murders: A Review Essay
}

\section{LAWRENCE H. LARSEN AND DAVID N. ATKINSON}

Villisca: The True Account of the Unsolved Mass Murder that Stunned the Nation, by Roy Marshall. Chula Vista, CA: Aventine Press, 2003. 388 pp. Illustrations. \$20.95 paper.

The Detectives, by Roy Marshall. Stanton: Roy Marshall, 2001. 124 pp. $\$ 14.95$, spiral notebook, paper.

The Interrogation of Reverend Kelly, by Roy Marshall. Stanton: Roy Marshall, 2001.52 pp. Illustrations. \$14.95, spiral notebook, paper.

Reminiscences of Events in the Life of F. F. Jones, edited by Tammy Rundle and Kelly Rundle. Los Angeles: Fourth Wall Press, 1997. 68 pp. Illustrations. \$8.95, spiral notebook, paper.

1912 Villisca, Iowa Axe Murders: Coroner's Inquest, edited by Kelly Rundle and Tammy Rundle. Los Angeles: Fourth Wall Press, 1995, 2003. 94 pp. Publisher's notes, facsimiles, illustrations. $\$ 19.95$ paper.

1912 Villisca, Iowa Axe Murders: Dope Sheet, edited by Kelly Rundle and Tammy Rundle. Los Angeles: Fourth Wall Press, 1996, 2003. Publisher's notes, facsimiles, illustrations. $\$ 25.95$ paper.

1912 Villisca, Iowa Axe Murders: Signed Statements, edited by Kelly Rundle and Tammy Rundle. Los Angeles: Fourth Wall Press, 1997, 2003. Publisher's notes, facsimiles, illustrations. $\$ 29.95$ paper.

Villisca Iowa's 1912 Axe Murders, featuring Edgar Epperly. VHS and DVD. Los Angeles: Fourth Wall Video, 1995; digitally remastered, 2003. \$24.95 DVD, \$19.95 VHS.

Exploring Villisca's Axe Murder House, with Edgar Epperly. VHS and DVD. Los Angeles: Fourth Wall Video, 1996; digitally remastered, 2003. \$24.95 DVD, \$19.95 VHS.

THE ANNALS OF IOWA 62 (Fall 2003). (C) The State Historical Society of Iowa, 2003. 
ON SUNDAY NIGHT, June 9, 1912, eight persons died in an axe murder in a plain two-story home on a quiet residential street in the southwestern Iowa town of Villisca. The Montgomery County community of 2,500 was about 50 miles east of Council Bluffs on the busy main line of the Chicago, Burlington and Quincy Railroad. The victims were Josiah and Sara Moore, both in their forties, their four children, and two visiting daughters of a Montgomery County farm couple, Joseph and Sarah Stillinger. Josiah Moore was a Villisca businessman, the manager of the local John Deere dealership. Moore, his wife, and the six children were last seen at about 10:00 p.m. on the Sunday evening of the crime, returning from a special children's service at a Presbyterian church. All were found murdered in their beds.

Following the discovery of the bodies on Monday morning, June 10, a widespread effort failed to find any credible suspects. Crack bloodhounds lost a scent at a river fork south of town. Hastily formed posses unsuccessfully scoured the surrounding countryside. Several individuals, detained and soon released, proved that they had been somewhere else on the night of the murder. Attempts to link the crime to other regional axe murders failed. No relative of the Moores or Stillingers appeared to have any connection with the crime.

When a federal criminologist arrived in Villisca and suggested that a local party might have been responsible, irate citizens called him a drunk and ran him out of town. In the first hours after the discovery of the bodies, local officials had totally botched the crime scene. The coroner had not even bothered to take notes on the condition of the bodies. The town marshal had allowed dozens of spectators to walk through the Moores' house to view the victims and to handle the murder axe left behind by the killer. As time passed, without solid evidence and no suspects, let alone a motive, it appeared that the Villisca axe murders would remain unsolved, fading into memory, a footnote in Iowa's crime history. But all of that changed in 1916.

As part of the continuing investigation, Iowa and Villisca authorities contracted with the William J. Burns National Detective Agency, which assigned fifty-year-old James Newton Wilkerson, a former Texas attorney and skilled orator, to the case. On June 12, 1916, Wilkerson claimed that he had found the 
"Villisca Axe Man." He assisted Kansas City, Kansas, lawmen in the arrest of William Mansfield, a packing plant sausage stuffer. Mansfield, a military deserter and bigamist whom Wilkerson called "Insane Blackie," was a labor organizer. Members of his immediate family had been axed to death in 1915 in Blue Island, Illinois. Wilkerson, with the permission of the Kansas City police, subjected Mansfield to a brutal "third degree" interrogation but failed to secure a confession. In July 1916 a Montgomery County grand jury refused to indict Mansfield, and he went free.

Wilkerson charged that the grand jury was fixed by the culprit behind the crime, Frank Fernando Jones, age 57, a state senator, a J. I. Case implement dealer, Josiah Moore's one-time employer, and the richest person in Villisca. In a series of speeches, Wilkerson claimed that Jones had hired Mansfield to murder Moore, possibly with the assistance of Jones's son, 37-year-old Albert Jones. The alleged motive was that Moore, a business rival, was carrying on an illicit affair with Albert Jones's wife, a former primary schoolteacher. Frank Jones sued Wilkerson for libel and, rather surprisingly, lost the case.

In the spring of 1917, a new Montgomery County grand jury investigated the murders. After hearing more than a hundred witnesses from a list provided by Wilkerson, it found no evidence of any involvement by Frank Jones or anyone else. Republican Iowa Attorney General Horace Havner and a special assistant, F. F. Faville, former United States Attorney for the Northern District of Iowa, played leading roles in the grand jury proceedings. Wilkerson, who said he planned to move from Missouri to Montgomery County, organized his own statewide organization, the Iowa Protective Association, and politicized the grand jury investigation. In a series of public appearances, he violently attacked the governor of Iowa, the state legislature, and the Des Moines Register, claiming a vast conspiracy existed to protect Frank Jones. The state fired Wilkerson, and the legislature passed a law intended to restrain detectives from making public statements, but Wilkerson, a rising force in Iowa politics, continued his increasingly virulent verbal attacks. After the United States went to war with Germany in April 1917, Wilkerson smeared Havner as a pro-German sympathizer. 
In May 1917 the grand jury, in what almost appeared an afterthought, indicted George Lyn Jacklen Kelly, an itinerant minister who had preached at the Presbyterian church in Villisca on the Sunday morning of the crime. Kelly, born in England in 1878 and a former evangelist in the slums of London, was a troubled individual. A convicted sexual predator and suspected firebug and Peeping Tom, he had been confined in a federal mental hospital until freed on the grounds that he was no longer dangerous. A small man, he seemed an unlikely axe murderer; but his subsequent comments and behavior drew attention to him. The state argued that he had slaughtered the six Moores and two Stillinger girls in a sexual frenzy. Kelly had claimed on several occasions that he was the perpetrator and, on the eve of his sensational trial in the fall of 1917, gave a detailed confession. He said that God had directed him to the Moore house, ordering him to slay the two adults and the little children. Havner and Faville, the lead prosecutors, accepted Kelly's version of events and believed that he had literally acted on his hallucinations. The state failed to convince juries of its case in two trials. The first ended in a hung jury, eleven members for acquittal and one for guilty by reason of insanity. The jury in a second trial found Kelly not guilty after five hours of deliberation. That ended the state's attempt to find the Villisca axe murderer; no other individual was ever charged in the case.

The principals in the case had varying fates. Kelly returned to preaching and was said to have died in a Long Island mental hospital in the 1950s. An adultery scandal and the embezzlement of the funds of the Iowa Protective Association ruined Wilkerson, and he left the state; he was working as a carnival exhibitor shortly before his death in 1944. Mansfield returned to labor organizing and was accused of murder in a labor disturbance in Sioux City but was not tried; he died in Milwaukee in the 1950s. Havner lost badly in the 1920 Republican primary for governor; he left elective politics and became a defense lawyer. Faville went on to become a distinguished justice on the Iowa Supreme Court. Albert Jones died of a stroke in 1935. Frank Jones remained the leading citizen of Villisca until his death in 1941. 
UNSOLVED MYSTERIES have a lasting fascination (witness Jack the Ripper), and the Villisca outrage has been no exception. Material on the Internet has added to its notoriety. Kelly Rundle and Tammy Rundle of Fourth Wall Films produced a documentary film, Villisca: Living with a Mystery, which premiered at the State Historical Building in Des Moines in June 2004. A novel loosely based on the facts of the case attributed the crime to a love triangle.' A master's thesis at Northwest Missouri State University concluded that Kelly had acquired knowledge of the murders by witnessing the murder of the two Stillinger girls through an unshaded window while prowling around the house during the murder. ${ }^{2}$ Whoever the killer and however the murders may have happened, the axe murders became a tale of Iowa-kept alive by word-of-mouth, occasional media stories, and memory.

As the town's population declined by over a thousand from 1912 to 2004, enterprising Villisca citizens have used the case to promote tourism in the fading railroad town. A museum in the building that housed Josiah Moore's store displays artifacts from Villisca's early years. The Moore house is a historic site. Both the museum and house are privately owned by the same person. In recent years, special events in Villisca have commemorated the murders, including historical presentations in the old Rialto Theater.

The first comprehensive account of the murders appeared in print in 2003, when Roy Marshall published Villisca: The True Account of the Unsolved 1912 Mass Murder that Stunned the Nation. Marshall focuses on the conflict between Frank Jones and Wilkerson, although he also considers other aspects of the story. The book is descriptive, but somewhat lacking in evidentiary analysis. There is no index, no bibliography, and no footnotes. Sometimes, sources are not evident from the text, so at least some documentation would have been useful. All in all, however, Marshall has written a better-than-average true crime story.

1. Stephen Bowman, Morning Ran Red (Omaha, NE, 1986).

2. Christina Lynn Person, "Iowa's Infamous Unsolved Crime: The Villisca Ax Murders of 1912" (M.A. thesis, Northwest Missouri State University, 1995). 
Two 2001 booklets issued by Marshall reproduce primary documents concerning the axe murders. The Detectives contains copies of reports by detectives hired by the state to investigate the crime. The Interrogation of Reverend Kelly is based on transcripts made by court reporters at a night session during which Kelly confessed that he was the Villisca axe murderer.

The Fourth Wall Press has reissued and upgraded three facsimile publications. The 1912 Villisca Axe Murders: Coroner's Inquest contains the proceedings of the inquest on the crime. The 1912 Villisca, Iowa Axe Murder Dope Sheet, a long document dictated by Wilkerson, describes his investigation of the murders, explaining why he thought the evidence he collected proved that Frank Jones should be indicted for the murders. The "Dope Sheet" was the basis of the 1917 grand jury investigation. The 1912 Villisca, Iowa Axe Murders: Signed Statements has selected affidavits taken for the 1917 grand jury. These fragmentary collections of primary sources contain no analysis. An additional Fourth Wall booklet is still in print: Reminiscences of Events in the Life of F. F. Jones, 1855-1940, edited by Kelly Rundle and Tammy Rundle. Jones's reminiscences have little on the murders. Fourth Wall's reopened Web site, "VILLISCA Emporium," promotes the film and, in addition, has information about the crime and photographs of some of the main characters in the tragedy. ${ }^{3}$

Of broader scope are two videocassettes recently released in new editions by Fourth Wall. The videos are built around entertaining, well-crafted, informative, and somewhat folksy performances by Edgar Epperly, a professor emeritus at Luther College. Epperly, a leading authority on the axe murders, has spent many years working with the evidence. One video, Villisca Iowa's 1912 Axe Murders, is a rendition of a live performance by Epperly at the Rialto Theater in Villisca. The other, Exploring Villisca's Axe Murder House, includes such features as Kelly's confession and "Internet References." Epperly shows how Wilkerson built a case against Jones based on flawed circumstantial evidence. Epperly finds Kelly a more plausible suspect than Jones.

3. The site, <www.villisca.com/emporium>, also offers for sale all of the publications reviewed here, including those not published by Fourth Wall Press, along with other books and videos related to the murders. 
Marshall's book, Fourth Wall's publications; and Epperly's presentations, like much of the other writings on the Villisca crime, focus in one way or another on the mystery of what happened on that June night in 1912. Consequently, much remains to be done. Historical perspective needs to be tightened. For example, weather bureau records for the murder night, located in the National Archives-Central Plains in Kansas City, Missouri, can be measured against newspaper accounts of the weather on the night of the murders. To what extent were the area rivers affected by rising water, thus affecting the searches? In addition, the legal evidence needs more rigorous evaluation, and the witnesses before the 1917 grand jury evaluated in that light. Finally, there may be something to be learned from the sort of crime profiling used by modern-day criminologists. In any event, the Villisca murders, absent DNA analysis, have a surprising contemporary aspect to them. Because they were so heinous and because the cast of townspeople involved in the aftermath was so diverse and interesting, it is not likely that the old case will be soon forgotten. 
Copyright of Annals of Iowa is the property of State of Iowa, by \& through the State Historical Society of Iowa and its content may not be copied or emailed to multiple sites or posted to a listserv without the copyright holder's express written permission. However, users may print, download, or email articles for individual use. 